\title{
Description of the immature stages of Sigara (Tropocorixa) jensenhaarupi (Hemiptera: Heteroptera: Corixidae: Corixini), with ecological notes
}

\section{Descripción de los estadios larvales de Sigara (Tropocorixa) jensenhaarupi (Heteroptera: Corixidae), con notas acerca de su ecología}

\author{
María Cecilia Melo $^{1 *}$ and Erica Elizabeth Scheibler ${ }^{2}$ \\ ${ }^{1}$ Departamento Sistemática, Instituto de Limnología "R.A. Ringuelet” (ILPLA) (CCT La Plata CONICET- UNLP), C.C. 712 , 1900 La Plata, Argentina. \\ ${ }^{2}$ Laboratorio de Entomología, Instituto Argentino de Investigaciones de las Zonas Áridas (IADIZA, CCT CONICET, Mendoza), C.C. 507, 5500 Men- \\ doza, Argentina. \\ *Correspondent: cecimelo@ilpla.edu.ar
}

\begin{abstract}
Sigara (Tropocorixa) jensenhaarupi Jaczewski is the smallest species of the subgenus ranging from 4.2-4.7 $\mathrm{mm}$, and it is characterized by the absence of a strigil, the small and narrow genital capsule with a short hypandrium in males, and the shape of the abdominal tergite VII in females. This species is endemic to the Patagonian subregion (Andean region) in Argentina. A monthly sampling study was performed during a year in northern Mendoza, and additional material was collected in southern Mendoza, more precisely from Bañado Carilauquen in the Llancanelo Lake Reserve (Malargüe Department). Since little is known about the ecological requirements of $S$. (T.) jensenhaarupi, herein we describe its habitat, the environmental conditions and its association with other macroinvertebrates. Also, we provide a morphological description of larval stages, and provide new records of this species.
\end{abstract}

Key words: Andean region, Argentina, ecological requirements, Hemiptera, larval stages, morphology, new records.

Resumen. Sigara (Tropocorixa) jensenhaarupi Jaczewski es la especie más pequeña del subgénero (4.2-4.7 mm), y se caracteriza por la ausencia de estrigilo, la cápsula genital masculina pequeña y angosta con el hipandro corto, y la forma característica del tergito abdominal VII en las hembras. Esta especie es endémica de la subregión Patagónica (región Andina) en Argentina. Se realizaron muestreos mensuales durante un año en el norte de la provincia de Mendoza, material adicional fue recolectado en el sur de la provincia, más precisamente en el Bañado Carilauquen en la Reserva Laguna Llancanelo (Departamento de Malargüe). Poco se conoce acerca de los requerimientos ecológicos de $S$. (T.) jensenhaarupi, por lo que en este trabajo describimos su hábitat, las condiciones ambientales y su asociación con otros macroinvertebrados. Además, describimos los estadios larvales y damos nuevos registros de esta especie.

Palabras clave: región andina, Argentina, requerimientos ecológicos, Hemiptera, estadios larvales, morfología, nuevos registros.

\section{Introduction}

Sigara (Tropocorixa) jensenhaarupi Jaczewski 1927 is the smallest species of the subgenus ranging from 4.2-4.7 mm (Bachmann 1979; 1981), and it is characterized by the absence of a strigil, the small and narrow genital capsule with a short hypandrium in males, and the shape of the abdominal tergite VII in females. According to Hungerford (1948) the absence of strigil is a secondary loss, and although there are other genera, as Callicorixa White and Centrocorisa Lundblad, which lack strigil, important characters such as the chaetotaxy of the male palae and

Recibido: 10 febrero 2010; aceptado: 06 mayo 2010 morphology of the right paramere lead to the inclusion of S. jensenhaarupi in the subgenus Tropocorixa Hutchinson.

This species is endemic to Argentina, and following the biogeographical scheme of Morrone (2001b), from the Patagonian subregion (Andean region). This subregion extends from the center of Mendoza province to the south including Neuquén, Río Negro, Chubut, and Santa Cruz up to the north of Tierra del Fuego province (Morrone, 2001a, b). According to Bachmann (1981), this species is not frequently found, as it lives in semipermanent waters (meanders and floodings) with high values of salinity. Bachmann (1979) mentioned that populations of $S$. (T.) jensenhaarupi are reduced and isolated, because it lives in extremely arid regions. Previous authors reported it from the Negro river valley (near General Roca, Río Negro 
province), from flooding of the Valcheta stream, from a small pond in Sierra Grande (Río Negro province), and from the Chadileufú river (Puelches, La Pampa province) (Bachmann, 1981; Melo, 2009; Muzón et al., 2010). During a year in northwestern Mendoza province and several specimens of $S$. (T.) jensenhaarupi were caught, which included both adults and larvae. Other specimens were collected in southern Mendoza province, in the Bañado Carilauquen in the Llancanelo Lake Provincial Fauna Reserve (Malargüe); these samples belong to a seasonal ecological study to evaluate the macroinvertebrate biodiversity along this arid wetland (Scheibler and Ciocco, in press).

Due to the fact that, so far, little is known about the ecological requirements of this species, herein we describe its habitat, its environmental conditions and its association with other macroinvertebrates. Also, we provide a morphological description of larval stadia, and give new records in northern and southern Mendoza province, Argentina.

\section{Materials and methods}

Study areas. The province of Mendoza (Argentina) stretches from the base of the Andes to the western flatland between $32^{\circ}-37^{\circ} 35^{\prime} \mathrm{S}$ and $66^{\circ} 30^{\prime}-70^{\circ} 35^{\prime} \mathrm{W}$, over an area of $150.839 \mathrm{~km}^{2}$. The region includes high mountains (over $2000 \mathrm{~m}$ a.s.l.) and valleys, with the Aconcagua (6 $962 \mathrm{~m}$ a.s.1.) in the Cordillera Principal of the Aconcagua Provincial Park. Mendoza presents an arid to semiarid climate; annual rainfalls slightly surpass 250 $\mathrm{mm}$ per year and increases to the south $(200-400 \mathrm{~mm})$ because of the influence of the western and southwestern anticiclonal winds, which discharge humidity in the Cordillera Principal. Snow is the predominant precipitation on the Andes mountain range, with an annual rainfall of $300-1000 \mathrm{~mm}$. The precipitations and glaciers form the rivers which are the main source of water for humans, and also for agricultural, livestock farming and industrial use. In general, soils are sandy and very permeable (Departamento General de Irrigación, 1997).

The specimens studied were collected in 11 sites following a latitudinal gradient. We divided them into 2 sectors: northern Mendoza and southern Mendoza (Fig. 1; Table 1).

Northern sector: The first 2 sites are located in the Uspallata valley. This valley is characterized by an arid climate with an annual mean precipitation of $136.3 \mathrm{~mm}$. At higher altitudes, the vegetation is characterised by bushes of Adesmia horrida Gillies ex Hook. et Arn. and Larrea divaricata Cav. (Carretero, 2000). In the lower areas the bushes are formed by Larrea cuneifolia Cav. (Ambrosetti and Méndez, 1986), and in the banks of the Uspallata stream the riparian vegetation consists of Cortaderia rudiuscula Stapf and Proustia cuneifolia D. Don.

1) Tambillos Dam (TAMB), located in the Cordillera Frontal at $2451 \mathrm{~m}$ a.s.1., it is a permanent system fed by Tambillos stream, which belongs to the Cordillera del Tigre sub basin.

2) Uspallata stream and adjacent areas (USP), constitute a mixed environment (lotic-lentic), located in the depression of the Uspallata valley, between the Cordillera Frontal and the Precordillera, at $1890 \mathrm{~m}$ a.s.l.

3) Las Cerrajas pond (CANG), commonly known as Los Cangrejos lagoon, $35 \mathrm{Km}$ E Uspallata, in the higher part of the Sierra de Uspallata at $2400 \mathrm{~m}$ a.s.l. The rainfall is scarce and the soil is formed by coarse, sand and rocks. The surrounding vegetation is mainly composed by grasslands of Stipa scirpea Speg., S. vaginata Phil., S. speciosa var. parva Roig, and S. chrysophylla Desv., Verbena uniflora Phil., V. erinacea Gillies and Hook., and Baccharis incarum (Wedd.), and in the lower parts by Adesmia horrida (Ambrosetti et al., 1986).

4) Potrerillos Dam (POTR), and nearby area at 1407 $\mathrm{m}$ a.s.l. The Potrerillos Dam is fed by the Mendoza River. The sampling was performed in the banks of the dam, in an area with abundant Poplar trees (Populus sp.; Salicaceae) which belonged to a former camping ground, flooded by the river when there was constructed.

5) Viborón lagoon and nearby ponds dam (VIB), at $630 \mathrm{~m}$ a.s.l., located in the northwestern of the Maipú Department. This is a permanent lagoon dominated by Typha dominguensis Pers. and Scirpus californicus (C.A. Mey.), with abundant Cortaderia selloana (Schult. and Schult.) on the shores, and in the parts prone to waterlogging and with a high salinity there are Salicornia ambigua (Michx.) and Distichlis spicata (L.) Greene. Its main tributary is the Reyes stream (Contreras and Fernández, 1980).

Southern sector: 6) Bañado Carilauquen (BC), located the west of Llancanelo Lake, it is a saline wetland with a mean depth of $30 \mathrm{~cm}$, occupying $65000 \mathrm{Ha}$. The altitude is ca. $1300 \mathrm{~m}$ a.s.l., between $35^{\circ} 30^{\prime}-36^{\circ} \mathrm{S}$ and $69^{\circ}-69^{\circ} 15^{\prime} \mathrm{W}$. It is shaped by the input from the river Malargüe (main tributary), streams Chacay, Alamo, Mocho and Durazno, and several intermitent streams including the Carilauquen that travels $10 \mathrm{~km}$ to the Llancanelo Lake. The dominant vegetation consists of hygrophilous macrophytes as Scirpus californicus, Cortadeira selloana and Chara vulgaris Linné (Sosa et al., 1989; Peralta and Fuentes, 2005). The sampled sites were located at the beginning and in the middle of the bañado and were named according to their location within the longitudinal gradient of the 


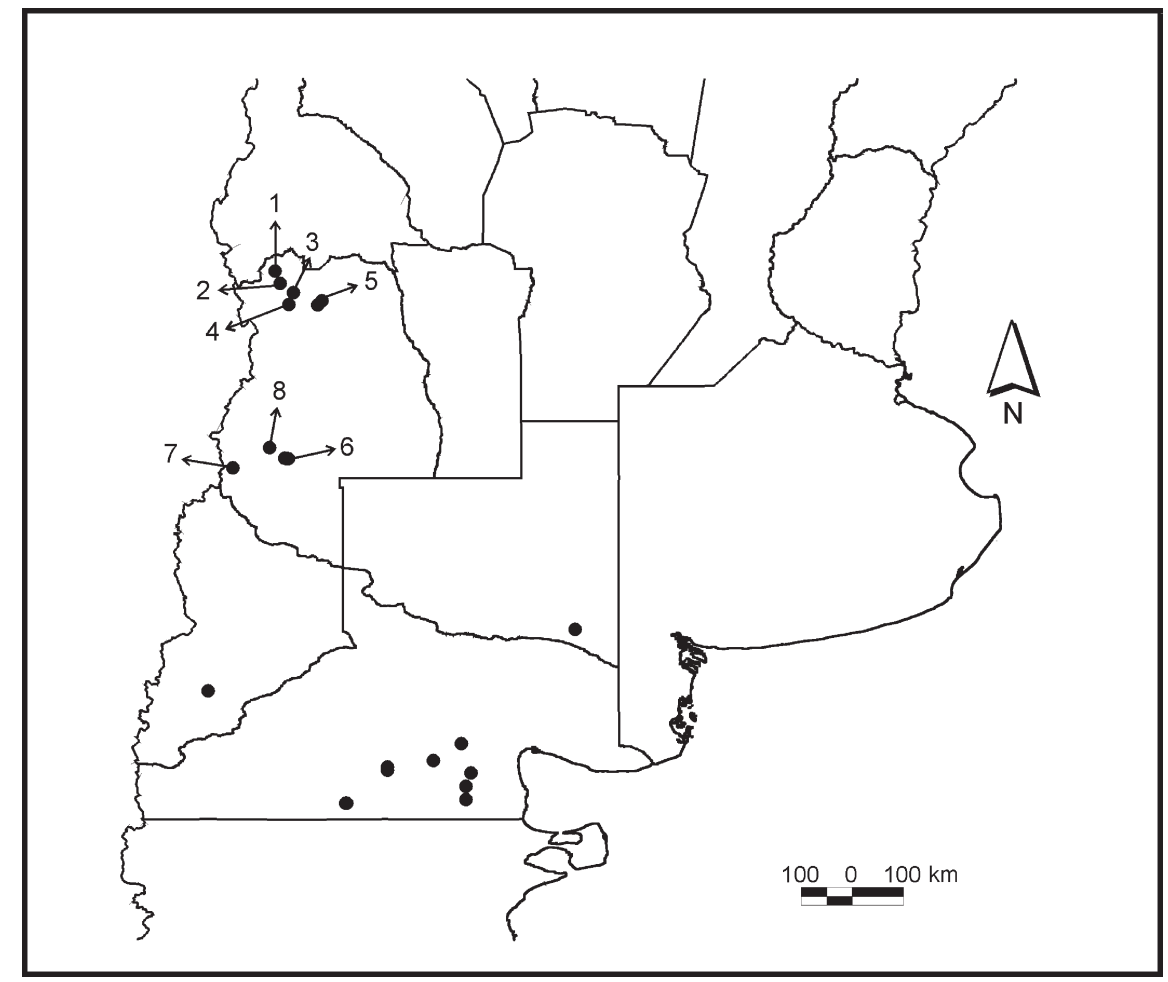

Figure 1. Map showing the geographic distribution of Sigara (Tropocorixa) jensenhaarupi Jaczweski. Numbers correspond to sampled sites in Mendoza province (Argentina) listed in Table 1.

system: headwaters (HD), higher middle reach (HMR), central middle reach (CMR), and lower middle reach (LMR) (Ciocco and Scheibler, 2008).

7) Loicas (LOICAS), a temporary pond located at 1661 $\mathrm{m}$ a.s.l., in the Pehuenche International Crossing, national route 145 , parallel to Chico river $\left(12.81 \mathrm{~m}^{3} \mathrm{~s}^{-1}\right.$ annual average). It is located in the High Andes and belongs to the High Andean steppe. The climate is cold with a wide daily temperature amplitude. Annual precipitation averages 100$200 \mathrm{~mm}$, mainly in the form of snow (Subsecretaría de Recursos Hídricos, 2002; 2004).

8) Tres Lagunas (TLAG), permanent? lagoon, $3 \mathrm{~km} \mathrm{E}$ from Malargüe, at $1400 \mathrm{~m}$ a.s.1.

\section{Sampling}

Northern sector: Monthly quantitative samplings were performed during 2007 and 2008, in 5 sites along an altitudinal gradient parallel to the Mendoza river, from Horcones lagoon to Potrerillos. Sigara (T.) jensenhaarupi was found in 3 sites: TAMB, USP y POTR. During September, November, December and January POTR was not sampled because it was dry . Sigara (T.) jensenhaarupi was also found in ponds and nearby areas of the Viborón lagoon (VIB), which were sampled qualitatively in October and November 2007. The following environmental variables were measured: air and water temperature $\left({ }^{\circ} \mathrm{C}\right.$; mercury thermometer), environmental humidity (\% Hygrotherm HT05), pH (Hanna pH meter, HI 9025), conductivity ( $\mu \mathrm{S} \mathrm{cm}^{-1}$; Hanna conductivity meter HI 9033), $\%$ Oxygen saturation (\% $\mathrm{O}_{2}$, Hach Dissolved Oxygen), depth (m; calibrated stick), transparency (m; Secchi disk), macrophytes and type of substrate.

Southern sector: Bañado Carilauquen: during 2000 and 2001 the bañado was sampled seasonally, in 5 sites along a longitudinal gradient from the headwaters to its mouth in the Llancanelo Lake. Sigara (T.) jensenhaarupi was collected in 4 of the 5 sampled sites: HD, HMR, CMR, and LMR. The following environmental variables were measured: ph, conductivity, transparency, water and air temperature, depth and type of substrate. Loicas and Tres Lagunas: these sites were sampled only once (16/XII/07) and the same environmental variables were measured.

Specimens were caught with a hand held net $(900$ $\mu \mathrm{m}$ mesh size), from within the vegetation and from the bottom of the lake/pond. In $\mathrm{BC}$ we also used a modified Petersen dredge ( $352 \mathrm{~cm}^{2}$ sampling area). All material collected was fixed in situ with $90 \%$ alcohol. Specimens were measured and photographed with a Leica DSC290 camera attached to a binocular microscope and using the software Leica Application Suite 2.8.1. SEM photographs of instar V were taken with a Jeol $6361 \mathrm{LV}$. Measurements are given in millimetres. Specimens were deposited at the Museo de La Plata (Argentina), and the Entomological Laboratory of CCT- Mendoza, CONICET (Argentina). 


\section{Description}

\section{Sigara (Tropocorixa) jensenhaarupi Jaczewski 1927}

Sigara (Sigara) jensen-haarupi Jaczewski, 1927: 253; Hungerford 1928: 174; Jaczewski 1933: 333.

Sigara (Tropocorixa) jensenhaarupi: Hungerford, 1948: 781; Bachmann 1962a: 23, 1962b: 24, 1963: 35, 1979: 334, 1981: 212; Contartese and Bachmann 1985: 90- 91; Bachmann 1998: 179; Morrone 2001a: 2, 2001b: 129; Morrone et al., 2004: 164, 166; Muzón et al., 2005: 56; Melo 2009: 180; Scheibler and Melo 2010: 108; Muzón et al., 2010: 113 .

Geographic distribution: ARGENTINA: provinces of Mendoza, Río Negro, La Pampa, and Neuquén. The studied material is depicted in Table 1, including collecting sites, dates, and type of environment in Mendoza province where permanent populations were found.

\section{Immature stages}

Measurements of all instars are shown in Table 3.

First instar (n=5) (Fig. 2). Body oval, apical region of abdomen straight with 2 pairs of long setae. General colour pale almost transparent. Eyes reddish brown. Head broadly rounded apically; frons convex with scarce setae. Antenna bisegmented. Scapus shorter than pedicellus, posterior border of pedicellus straight with long setae, anterior border slightly convex. Thorax: pronotum exposed, longer than mesonotum, but shorter than metanotum. Wing pads not developed. Setae absent. Profemur with scattered long setae on inner surface, and 2 long setae apically. Tibiotarsus with a dorsal row of long setae, an upper row of short spiniform setae, and a lower row of long setae, basal region with a short setae probably corresponding to the tibial comb. Mesofemur with sparse long setae ventrally, 2 longer setae apically on inner surface, and scarce short decumbent setae dorsally. Mesotibia and mesotarsus with sparse short setae, 2 elongate claws. Metafemur with 3 spiniform setae on inner apical region, and long and short setae dorsally. Metatibia with a row of short decumbent setae ventrally, scattered short setae and 3 stout longer setae apically. Metatarsus with a row of long setae dorsally and ventrally, and another row of short setae ventrally, 2 claws. Abdomen: abdominal segment I much shorter than posterior ones. Abdomen with 2 reddish heart-shape patches before scent gland openings IV and V. First pair of scents glands with the 2 openings and more contiguous than posterior ones.
Second instar (n=10) (Fig. 3). Darker than previous instar, with a longitudinal dark stripe along dorsal surface from apex of head to tip of abdomen. Pronotum exposed, glabrous. Mesothoracic wing pad slightly insinuated, metathoracic wing pads not developed.

Third instar $(\mathrm{n}=10)$ (Fig. 4). Similar to previous instar, except sternal region with abundant setae. Head: vertex acutely rounded. Occipital margin of head sinuate slightly produced at middle, with long setae on the sides. Thorax: pronotum hidden under head. Mesothoracic wing pads short, not reaching abdominal tergum I, metathoracic wing pads slightly insinuated. Long setae present on meso- and metanotum. Legs more setose than previous instar, tarsus III paddle- shape. Coxae and trochanters of all legs with hydrophobic setae. Profemur and metafemur with hydrophobic setae occupying almost $2 / 3$ of ventral region; lateral region of metafemur with long setae along margin of ventral hydrophobic area. Tibiotarsus with short decumbent setae on excavated region of pala, between upper and lower rows of setae. Tibial comb of anterior leg composed by 2 setae, of mesolegs by 3 setae. Abdomen: ventral region with abundant hydrophobic setae.

Fourth instar (n=10) (Fig. 5). Mesothoracic wing pads slightly surpassing metanotum; metathoracic wing pads reaching anterior margin of abdominal tergum I. Both with short setae much longer on inner lateral margins.

Fifth instar (n=10) (Fig. 6). Colour: pale brown, darkened at posterior margin of head (with a longitudinal dark stripe), and irregularly on wing pads and abdominal terga. Sternal region whitish. A reddish heart-shaped patch at middle of posterior margin of abdominal tergites IV and V (Fig. 6) just before scent gland openings. Eyes dark. Head: apex of head rounded, frons convex with scarce long decumbent setae, and chloride cells; dorsal region with scattered trichobothria. Rostrum with long setae on lateral margins. Thorax: pronotum short covered by head, with short setae longer on posterior margin. Mesonotum expanded medially with abundant long decumbent setae (Fig. 7); wing pads with abundant setae longer on inner lateral margins. Long lanceolate setae on inner margin at base of mesothoracic wing pads (Fig. 8), and on middle region of mesonotum (Fig. 9); apical region of wing pads with scattered spatulate setae externally (Fig. 10). Metanotum with long setae along the sides of mesothoracic wing pads, and shorter setae on inner posterior margin of metathoracic wing pads. Mesothoracic wing pad reaching posterior margin of abdominal tergum I, metathoracic wing pad slightly overpassing it. Metasternum short, apex rounded (Fig. 11). Legs: protrochanter with 6 campaniform sensilla; profemur with hydrophobic setae on basal half, and a few scattered spinules on ventral region and 3 spinules apically (Fig. 12); tibiotarsus elongate, tibial comb composed of 5 
setae. Pala with a dorsal row of 10 long setae (Fig. 12), an upper row of short setae, and a lower row of long setae extending from beyond middle of pala; 2 terminal claws. Mesocoxa, mesotrochanter and basal region of mesofemur with hydrophobic setae; mesofemur with longitudinal rows of spiniform setae more abundant ventrally, mesotibia and mesotarsus with similar setae, 2 terminal claws. Hind legs compressed; metafemur with hydrophobic setae occupying basal 2/3 almost reaching apex on ventral surface (Fig. 13), 4 spiniform setae dorsally, a tuft of long erect setae ventrally, and a few scattered spinules on inner surface; metatibia with semidecumbent spiniform setae on dorsal and ventral surfaces, glabrous laterally, and long thin setae ventrally; metatarsus paddle-shape with long setae (Fig. 14). Two terminal claws. Tibial comb present on meso- and metatibiae. Abdomen: scent gland openings on posterior margin of tergites III, IV and V; the first ones reduced, second and third well developed. Abdominal terga with abundant microtichia; sternal region with microtrichia, short setae and scattered long setae. Abdominal apex with long setae on lateral margins, and 2 tufts of longer setae posteriorly.

\section{Remarks on larval morphology}

The main characters to distinguish $S$. (T.) jensenhaarupi are the absence of strigil, the short and slender body, the shape of tergite VII in females and the male genital capsule. As most of these features are related to sexual dimorphism, their observation is not possible in the larval stage. Other characters observed in both adults and larvae are the highly extended hydrophobic area on the ventral side of metafemur (almost occupying 3/5 of metafemur length), and the metasternum that is always shorter than long with a rounded apex. In all instars, the synthlipsis is broader than the posterior margin of an eye; while in adults, this proportion changes and the synthlipsis is narrower than the posterior margin of an eye.

No other larvae of this subgenus have been described at the moment, so it is not possible to make comparisons. Little is known about the larvae of other genera. We can only say that we agree with previous works (Scheibler and Melo, 2010; Konopko and Melo, 2009) in the easy separation of the 5 instars based on: body length; absence, presence and development of wing pads; number of spines on the tibial comb of the tibiatarsus, absence or presence of the hydrophobic setose area on femora, and the chaetotaxy of abdominal sterna (sternites IV-VIII). The analysis of the measurements revealed that there is no allometric growth in the measured structures, but we could observe a more pronounced increase of the total length between instars 4 to 5 .

Environmental conditions: Main environmental parameters as well as the type of habitat where $S$. (T.) jensenhaarupi was found in Mendoza province are shown in tables 1- 2. The $\mathrm{pH}$ ranged from neutral to alkaline. The conductivity notably varied reaching maximum values in VIB $\left(4000 \mu \mathrm{S} \mathrm{cm}^{-1}\right)$ and minimum mean values in TAMB $\left(170.59 \mu \mathrm{S} \mathrm{cm}^{-1}\right)$. Water temperature reached maximum mean values in LOICAS $\left(27.10^{\circ} \mathrm{C}\right)$, and minimum mean values in CMR $\left(12.16^{\circ} \mathrm{C}\right)$. In general, the water showed high transparency and was well oxygenated. The substrate was composed by sand, clay and silt; in TAMB and USP the substrate also included pebble and boulder. In most of the studied systems prevailed the presence of Cortaderia sp. (Poaceae), Chara sp. (Characeae), Azolla sp. (Azollaceae), and filamentous algae (Clorophyta).

Macroinvertebrate associations: Associated with $S$. (T.) jensenhaarupi we found a high diversity of macroinvertebrates. In the northern sector, it was found together with: Coleoptera (adults and larvae): Berosus sp., Tropisternus sp., Tropisternus lateralis (Fabricius), T. flavescens d'Orchymont, T. setiger Germar, Enochrus gentilis Knisch, Lancetes nigriceps nordenskjoldi (Erichson), Liodessus flavofasciatus Steinheil, and Rhantus sp.; Hemiptera (adults and larvae): Belostoma bifoveolatum Spinola; Odonata (adults and larvae): Ishnura ultima Ris, I. fluviatilis Selys, I. cf. fluviatilis, Andinagrion peterseni (Ris), Rhionaeschna variegata (Fabricius), $R$. absoluta (Calvert), Progomphus joergenseni Ris, Erythrodiplax connata (Burmeister), E. corallina (Brauer), and Dasythemis mincki clara Ris; Ephemeroptera (larvae): Baetodes sp.; Amphipoda: Hyalella sp. (in a high density); Mollusca (shells): Heleobia kuesteri (Strobel), H. hatcheri Flores and Brugni, H. parchappii (D'Orbigny), Chilina mendozana Ströbel, Chilina sp., Pisidium chiquitanum Ituarte (Masi and Ciocco, 2008), and Lymnaea viator D’Orbigny (Ciocco et al., 2009).

In the southern sector, more specifically in the sites associated to the Bañado Carilauquen (Scheibler, 2007; Scheibler and Ciocco, in press) $S$. (T.) jensenhaarupi was found together with: Diptera (larvae): Cricotopus sp., Chironomus sp., Pseudochironomus sp., Dicrotendipes sp., Djalmabatista sp., Tanypus sp., Paratanytarsus sp., Polypedilum sp. (Chironomidae), Dixidae sp., Culicidae, Tabanidae (adults), Dolichopodidae sp., Ephydridae sp., and larvae of Dasyhelea sp. (Ceratopogonidae); Ephemeroptera (larvae): Caenis sp.; Trichoptera (larvae): Metrichia sp. and Oxyethira sp.; Coleoptera (adults): Hydrovatus sp., Lancetes biremis Riha, Laccornellus sp., Enochrus lameros Knisch, Desmopachria mendozana Steinheil, Haliplus sp., and Scirtidae sp.; Hemiptera (adults 

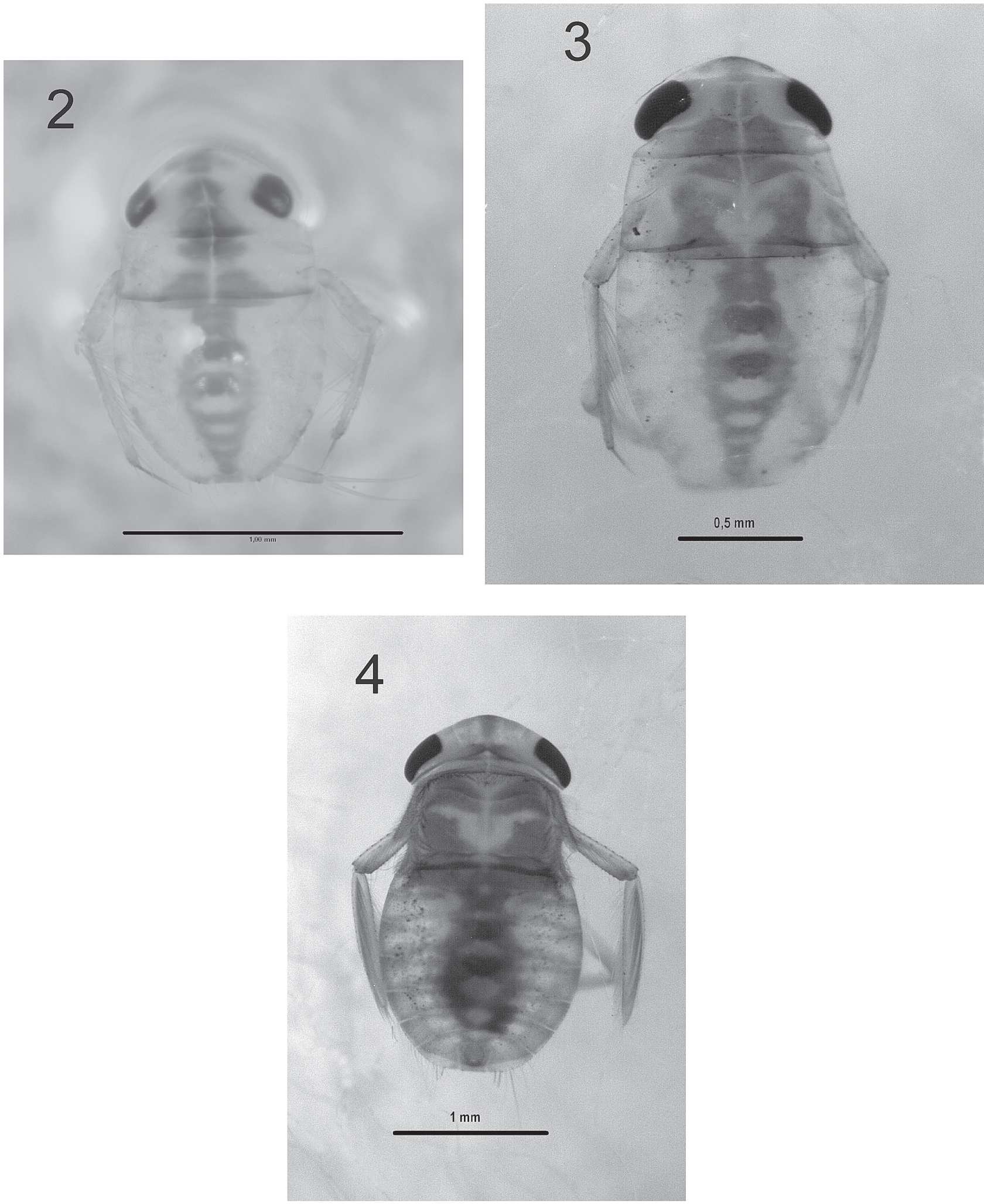

Figures 2-4. Sigara (Tropocorixa) jensenhaarupi Jaczweski, larval dorsal habitus. 2. First instar. 3. Second instar. 4. Third instar. 


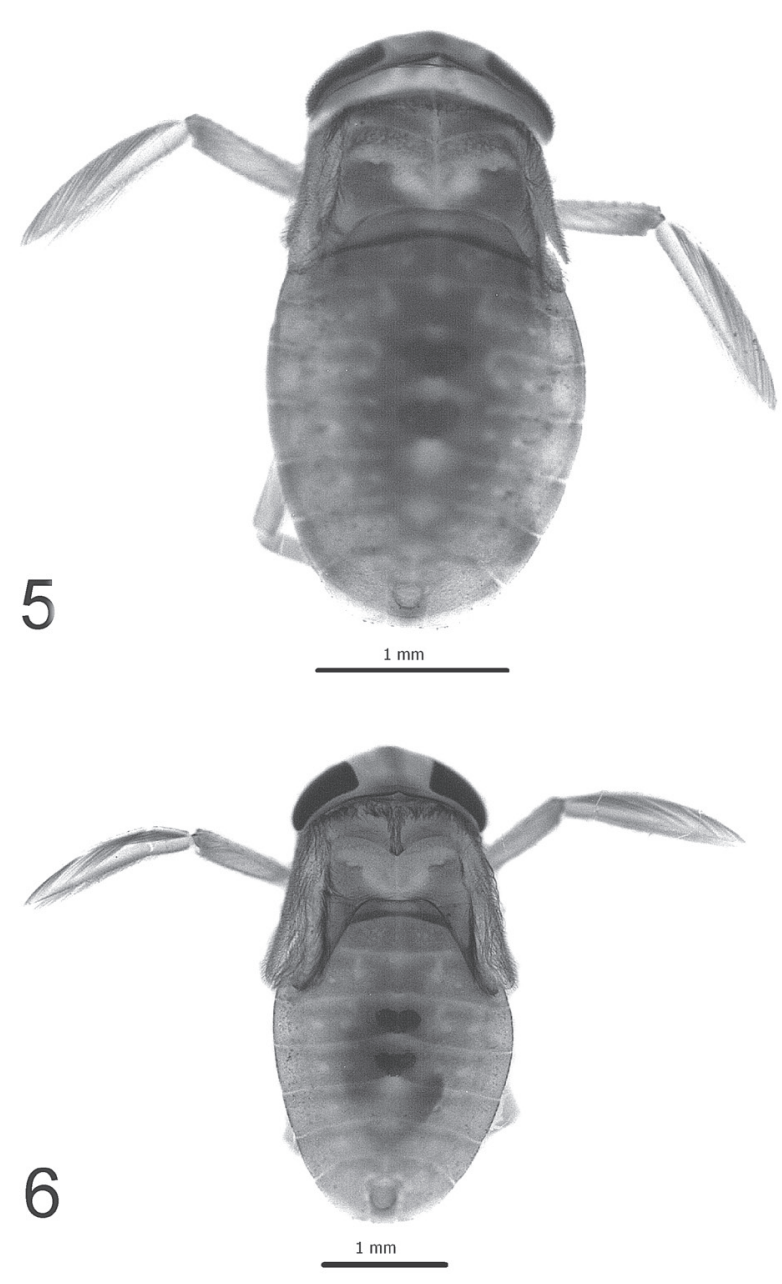

Figures 5-6. Sigara (Tropocorixa) jensenhaarupi Jaczweski, larval dorsal habitus. 5. Fourth instar. 6. Fifth instar.

and larvae): Sigara (Tropocorixa) rubyae (Hungerford), Notonecta (Paranecta) viscerens Blanchard, and Belostoma bifoveolatum; Amphipoda: Hyalella curvispina Shoemaker; Mollusca: Heleobia parchappii (D’Orbigny), H. hatchery (Pilsbry), Chilina mendozana, Biomphalaria peregrina (d'Orbigny), and Lymnaea viator; and other macroinvertebrates as Hirudinea, Turbellaria (Dugesidae), and Nematoda.

In LOICAS we found: Odonata (larvae): Rhionaeschna variegata, Cyanallagma interruptum (Selys), and Andinagrion peterseni; Coleoptera: Tropisternus setiger, Enochrus gentilis (Hydrophlilidae); Lancetes nigreceps nordenskjoldi, and Liodessus flavofasciatus (Dytiscidae); Diptera: Chironomidae (larvae); Crustacea: Hyalella sp., and Mollusca: Lymnaea viator.

Distributional patterns: S. (T.) jensenhaarupi shows an altitudinal distributional pattern (624-2 $450 \mathrm{~m}$ a.s.1.), and a latitudinal range (north- south of Mendoza province) in western Argentina. Larval and adults were found in different biogeographic provinces (Morrone, 2006): Andean region (TAMB and LOICAS sites), Patagonian province (TLAG and sites in Bañado Carilauquen), and Monte province (USP and POTR).

\section{Discussion}

Sigara (T.) jensenhaarupi presents a wide distribution in Andean and extra-Andean environments in Mendoza province. Larvae and adults were collected at several latitudes and altitudes in different types of water bodies (ponds, lagoons and dams), in both permanent and temporary environments. The environmental conditions also show a wide range of values. Environments where Sigara (T.) jensenhaarupi was found were oxygenated and transparent, had a neutral-alkaline $\mathrm{pH}$, with a wide range of conductivity; and with diverse species of vascular plants as part of the riparian vegetation and aquatic macrophytes. In northern Patagonia (Somuncura plateau), it presented also a wide distribution in temporary and/or permanent environments, with a considerable altitudinal range (210-1 $050 \mathrm{~m}$ a.s.1.). The species was found in a variety of water bodies as mallines, slopes (some of them with a thermal origin), streams, lagoons, and slopes located in rural areas; with scarce or abundant riparian vegetation constituted by Cortaderia sp., marsh vegetation, sediment formed by gravel, in environments highly impacted by cattle (sheep and goat) and by human activities (Muzón et al., 2005; Muzón et al., 2010).

We also observed that the species studied is associated with a notable amount of invertebrates. The macroinvertebrate composition in the sampled sites resulted to be dominated by aquatic insects, particularly Diptera and Coleoptera, common in these kinds of environments (Pinder et al., 2004). The species associated to Sigara (T.) jensenhaarupi vary between taxa inhabiting environments with better environmental conditions (permanent ponds, with stable, deep, transparent and vegetated waters and with low conductivity) such as Metrichia sp., Oxyethira sp., Chilina mendozana, Cricotopus sp., Dicrotendipes sp., Lancetes biremis, Hyalella curvispina, and Heleobia hatcheri), to species with a greater capacity to adaptation to changing environmental conditions and tolerant to hard environmental conditions (unstable, shallow, less vegetated waters, with high conductivity) such 

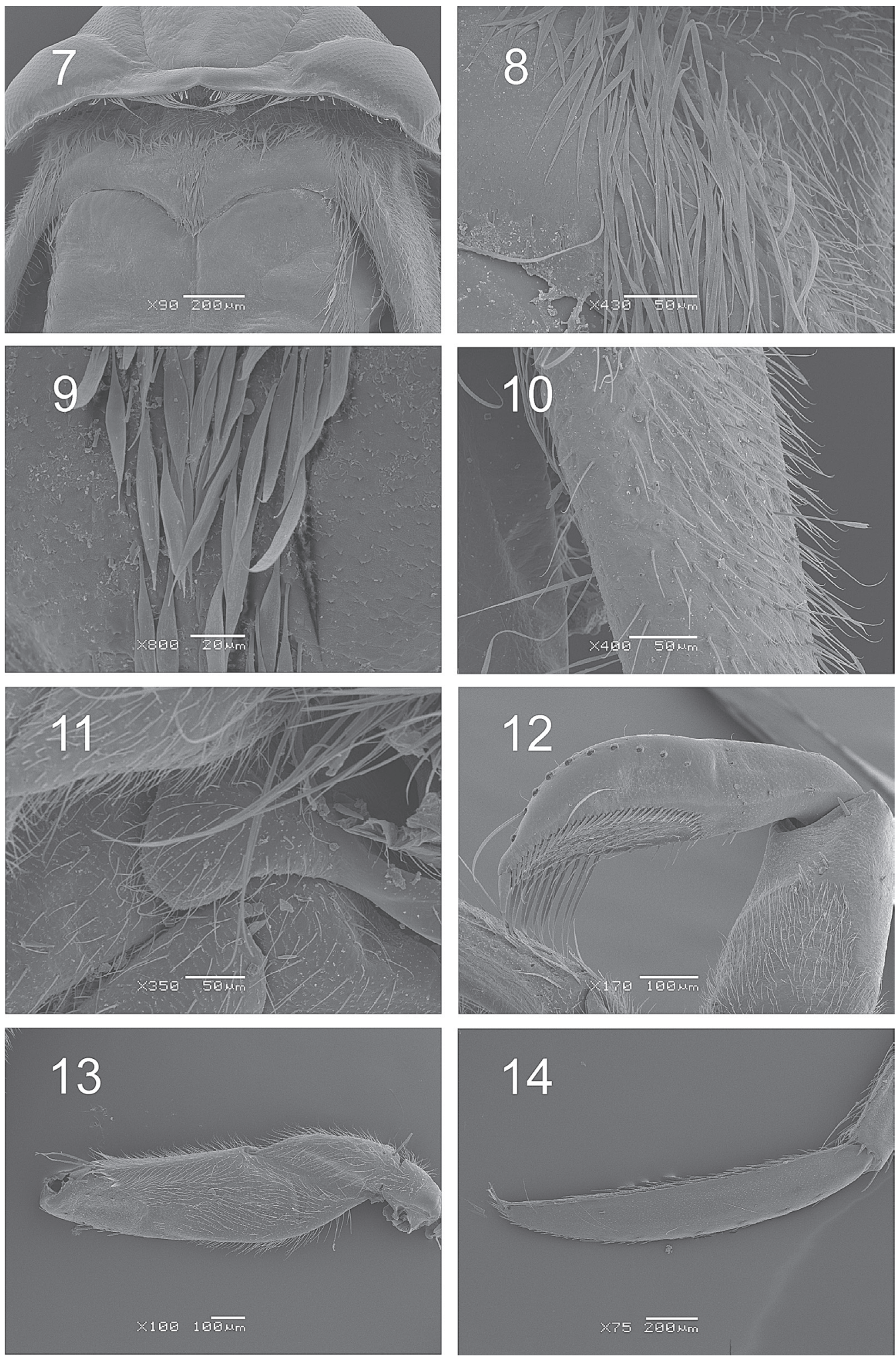

Figures 7-14. Sigara (Tropocorixa) jensenhaarupi Jaczweski, fifth instar. 7. Meso- and metanotum. 8. Setae on anterior region of mesonotum. 9. Setae on median region of mesonotum. 10. Setae on posterior region of mesothoracic wing pad. 11. Metasternum. 12. anterior leg. 13. Metafemur, 14. Metatarsus. 
as: Chironomus sp., Djalmabatista sp., Tanypus sp., Dasyhelea sp., Caenis sp., Tropisternus setiger, Liodessus sp., Haliplus sp., Rhionaeschna absoluta, Lymnaea viator, and Biomphalaria peregrina (Ciocco and Scheibler, 2008; Scheibler and Ciocco, in press).

\section{Acknowledgments}

We especially thank our colleagues from the Entomology Lab (IADIZA-CCT Mendoza CONICET) for their support during the fieldwork. We are especially grateful to Javier Muzón (ILPLA, CCT La PlataCONICET, UNLP) for his critical reading and suggestions that improved the manuscript and for Odonata specimens identifications; to Mariano Michat for Coleoptera identifications, to Sara Itzel Montemayor and Pablo Matías Dellapé (Museo de La Plata) for allowing us to access their laboratory and equipment. This study was supported by the Consejo Nacional de Investigaciones Científicas y Técnicas (CONICET), Argentina, and grant FONCYTPICT 01-11120 to Sergio Roig's project "Diversidad de Artrópodos en Ambientes Montanos del Centro Oeste Argentino".

\section{Literature cited}

Ambrosetti, J. A. and E. Méndez. 1986. La vegetación del Paso de Uspallata, Provincia de Mendoza, Argentina. Veröffentlichungen des Geobotanischen Institutes der ETH, Stiftung Rübel Zürich 91:141-180.

Bachmann, A. O. 1962a. Catálogo de las Corixidae de la República Argentina (Insecta, Hemiptera). Neotropica $8: 15-25$.

Bachmann, A. O. 1962b. Clave para determinación de las subfamilias, géneros y especies de las Corixidae de la República Argentina (Insecta, Hemiptera). Physis 23:2125.

Bachmann, A. O. 1963. Apuntes para una hidrobiología argentina. VI. Los Hemiptera Cryptocerata de la Patagonia extracordillerana. Physis 24:35-37.

Bachmann, A. O. 1979. Notas para una monografía de las Corixidae argentinas (Insecta, Heteroptera). Acta Zoológica Lilloana 35:305-349.

Bachmann, A. O. 1981. Insecta Hemiptera Corixidae. In Fauna de agua dulce de la República Argentina, R. A. Ringuelet (ed.). La Plata: Fundación para la Educación, la Ciencia y la Cultura. p. 1-270.

Bachmann, A. O. 1998. Cap. 16. Heteroptera acuáticos. In Biodiversidad de Artrópodos Argentinos, vol. 1, J. J. Morrone and S. Coscarón (eds.). Ediciones Sur, La Plata. p. 163-180.

Carretero, E. M. 2000. Vegetación de los Andes Centrales de la Argentina: El Valle de Uspallata, Mendoza. Boletín de la Sociedad Argentina de Botánica 34:127-148.

Ciocco, N. F. and E. E. Scheibler. 2008. Malacofauna of the littoral benthos of a saline lake in southern Mendoza, Argentina. Fundamental and Applied Limnology, Archiv für Hydrobiologie 172:87-98.

Ciocco, N. F. and C. I. Masi and E. E. Scheibler. 2009. Altitudinal distribution and water parameters related to the presence of the snail Lymnaea viator in Mendoza province, Argentina. (Abstract). Biocell 33:37-A66.

Contartese, A. L. and A. O. Bachmann. 1985. Distribución geográfica de las Corixidae argentinas (Insecta, Heteroptera). Physis, secc. B 43:89-92.

Contreras, J.R. and A. Fernández. 1980. Ecología de la avifauna de la laguna del Viborón, Departamento Maipú, provincia de Mendoza. Revista del Museo de Historia Natural de San Rafael (Mendoza), Argentina 8:3-14.

Departamento General de Irrigación. 1997. Preliminary Description of the Mendoza River Basin. Departamento General de Irrigación. Secretaría de Agricultura, Ganadería, Pesca y Alimentación de la Nación, Gobierno de Mendoza, Mendoza.

Hungerford, H. B. 1928. Some South American Corixidae. Bulletin of the Brooklyn Entomological Society 23:174180.

Hungerford, H. B. 1948. The Corixidae of the Western Hemisphere (Hemiptera). The University of Kansas Science Bulletin 32:1-827.

Jaczewski, T. 1927. Argentinian Corixidae collected by Mr. A.C. Jensen-Haarup. Annales Zoologici Musei PoloniciHistoriae Naturalis 6:251-261.

Jaczewski, T. 1933. Notes on Some South and Central American Corixidae. Annales Musei Zoologici Polonici 9:329-339.

Konopko, S. A. and M. C. Melo. 2009. Larval morphology of Ectemnostega (Ectemnostegella) montana (Lundblad 1928) (Hemiptera; Heteroptera: Corixidae: Corixinae), with an emphasis on chaetotaxy. Zootaxa 2315:1-18.

Masi, C. I. and N. F. Ciocco. 2008. Moluscos de la desembocadura del Arroyo Uspallata, Mendoza, Argentina. IV Congreso Argentino de Limnología. San Carlos de Bariloche-Río Negro-Argentina. 26-30 Octubre, 2008.

Melo, M. C. 2009. Biodiversidad de Heteroptera (Hemiptera) acuáticas y semiacuáticas de la Patagonia argentina. Revista de la Sociedad Entomológica Argentina 68:177185.

Morrone, J. J. 2001a. Review of the biogeographic provinces of the Patagonian subregion. Revista de la Sociedad Entomológica Argentina 60:1-8.

Morrone, J.J. 2001b. Biogeografía de América Latina y el 
Caribe. Manuales \& Tesis SEA, vol. 3. Zaragoza. 148 p.

Morrone, J. J. 2006. Biogeographic areas and transition zones of Latin America and the Caribbean islands, based on panbiogeographic and cladistic analyses of the entomofauna. Annual Review of Entomology 51:467-494.

Morrone, J. J., S. A. Mazzucconi and A. O. Bachmann. 2004. Distributional patterns of Chacoan water bugs (Heteroptera: Belostomatidae, Corixidae, Micronectidae and Gerridae). Hydrobiologia 523:159-173.

Muzón, J., G. R. Spinelli, P. Pessacq, N. Von Ellenrieder, A. L. Estévez, P. I. Marino, P. J. Pérez Goodwyn, E. B. Angrisano, F. Díaz, L. A. Fernández, S. Mazzucconi, G. Rossi and O. Salomón. 2005. Insectos acuáticos de la Meseta del Somuncura, Patagonia, Argentina: Inventario preliminar. Revista de la Sociedad Entomológica Argentina 64:47-68.

Muzón, J., G. R. Spinelli, G. C. Rossi, P. I. Marino, F. Díaz and M. C. Melo. 2010. Nuevas citas de insectos acuáticos para la Meseta del Somuncura, Patagonia, Argentina. Revista de la Sociedad Entomológica Argentina 69:111-116.

Peralta, P. and V. Fuentes. 2001. Vegetación Litoral. Estudio Base Cerro Bañado Carilauquen. Fundación Cricyt, Mendoza, Argentina. Technical Report. p. 1-22.

Peralta, P. and V. Fuentes. 2005. Fitobentos, fitoplancton y zooplancton litoral del bañado de Carilauquen, Cuenca de Llancanelo, Mendoza, Argentina. Limnética 24:183-198.
Pinder, A. M., S. A. Halse, J. M. McRae and R. J. Shiel. 2004. Aquatic invertebrate assemblages of wetlands and rivers in the wheatbelt region of Western Australia. Records of the Western Australian Museum Supplement 67:7-37.

Scheibler, E. E. 2007. Biodiversidad de insectos acuáticos en zonas áridas del centro-oeste andino (Mendoza, Argentina). Cuadernos de Biodiversidad 25:19-26.

Scheibler, E. E. and N. F. Ciocco. 2011. Macroinvertebrate assemblages' distribution along a saline wetland in hard environmental conditions from Central-West of Argentina. Limnologica 41:37-47.

Scheibler, E. E. and M. C. Melo. 2010. Description of immature stages of Ectemnostega (Ectemnostega) quadrata (Signoret 1885) (Heteroptera: Corixidae), with notes on ecological requirements of the species. Aquatic Insects 32:99-111.

Sosa, H., F. Videla and S. Puig. 1989. Marcación de límites biológicos del Sector NO de la Reserva Provincial Laguna de Llancanelo. Technical Report. Dirección de Recursos Renovables, Gobierno de la Provincia de Mendoza, Mendoza. Subsecretaría de Recursos Hídricos. 2002. Atlas Digital de los Recursos Hídricos Superficiales de la República Argentina (CD-ROM). Buenos Aires, Argentina.

Subsecretaría de Recursos Hídricos. 2004. Estadística Hidrológica de la República Argentina, Edición 2004. Buenos Aires. 


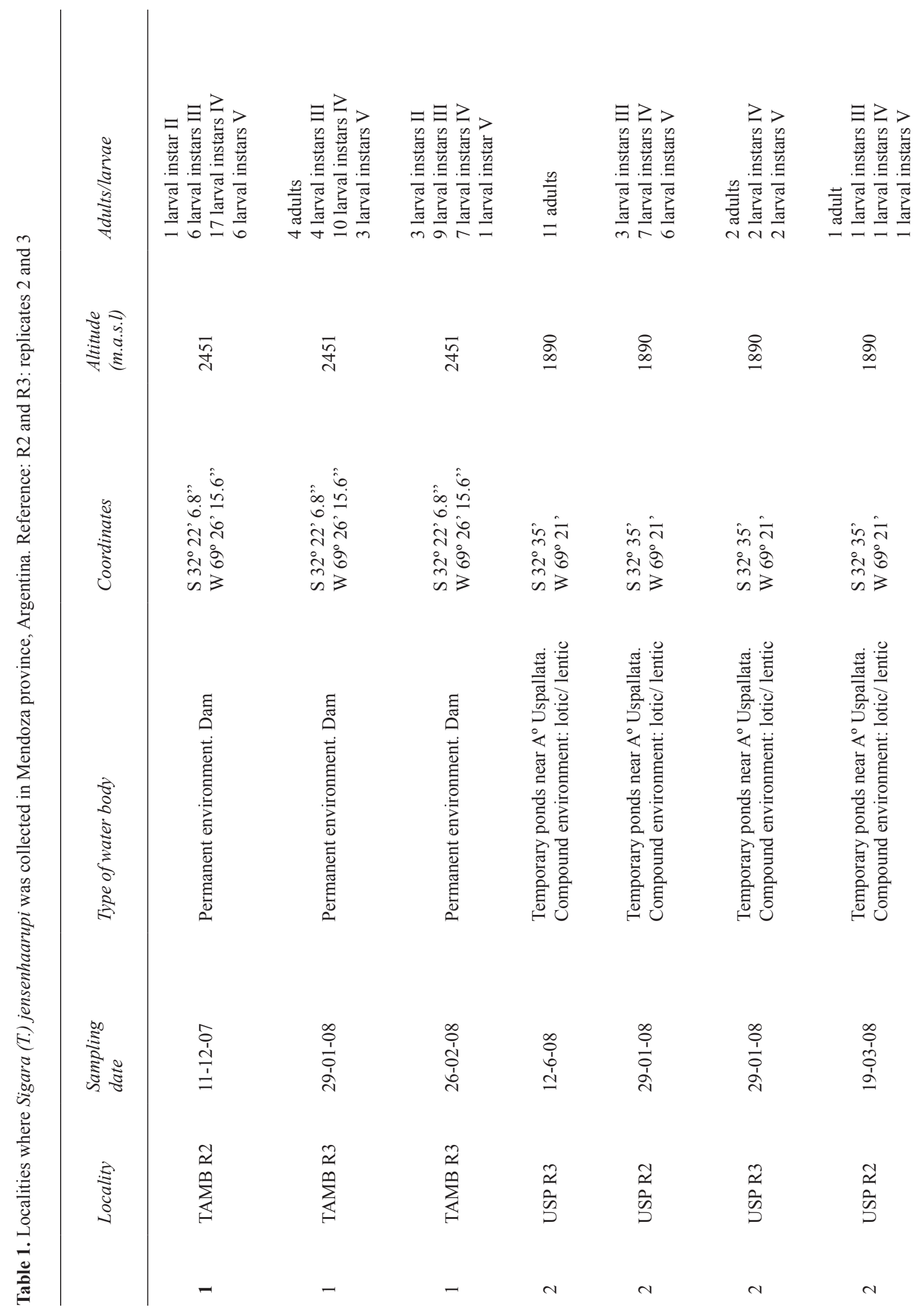




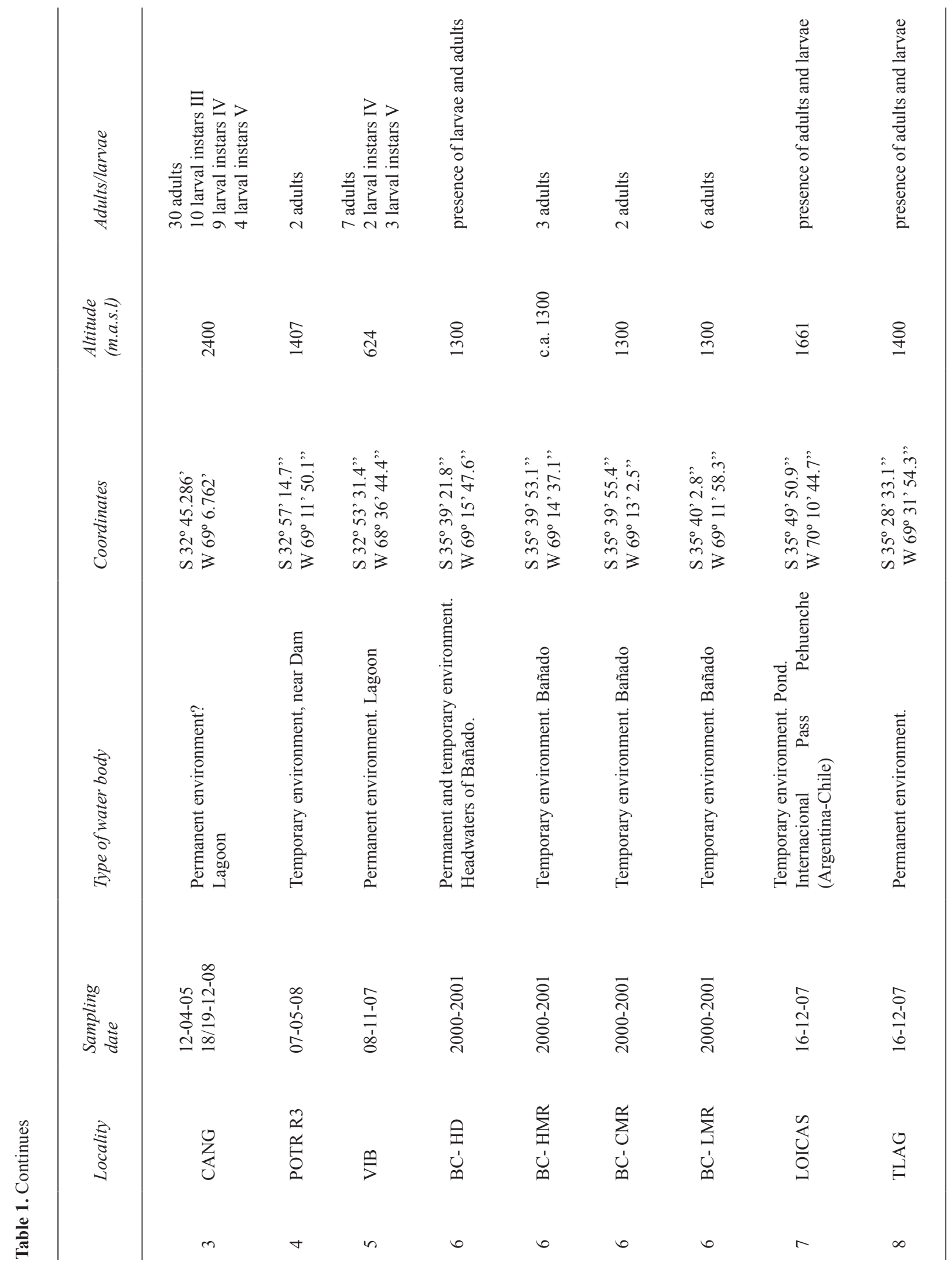




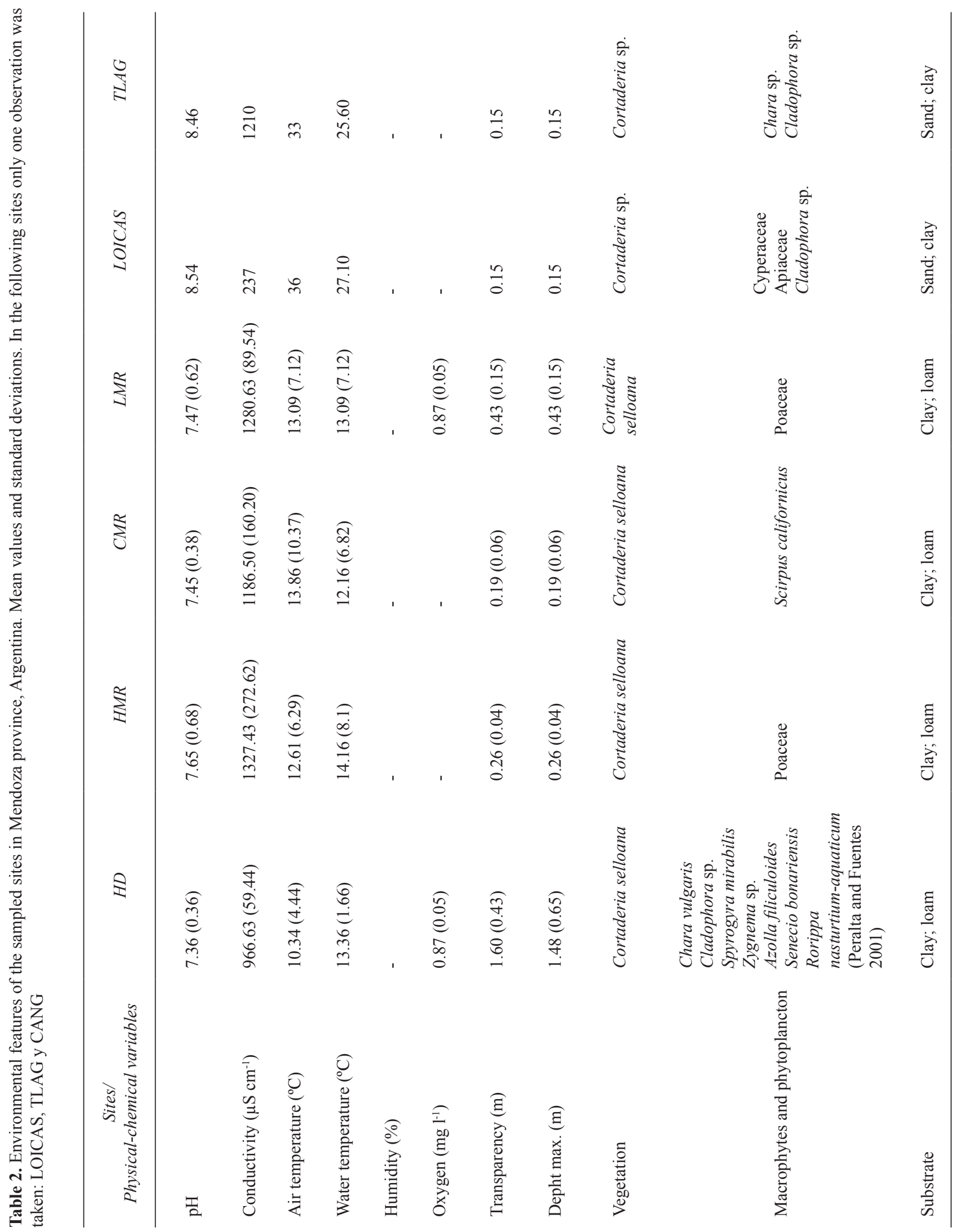




\begin{tabular}{|c|c|c|c|c|c|c|c|c|}
\hline \multirow{2}{*}{ 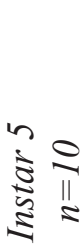 } & छี & ले & $\stackrel{\infty}{\infty}$ & ڤ్ & $\stackrel{l}{:}$ & $\stackrel{8}{8}$ & $\underset{\sim}{\sigma}$ & $\stackrel{\mathbb{2}}{\stackrel{\theta}{\rho}}$ \\
\hline & 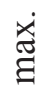 & $\begin{array}{l}\exists \\
\dot{\forall}\end{array}$ & $\begin{array}{l}\tilde{C} \\
\text { ì }\end{array}$ & $\stackrel{\text { oे }}{-}$ & $\stackrel{n}{\mathfrak{0}}$ & $\begin{array}{l}\mathbb{J} \\
\stackrel{0}{0}\end{array}$ & $\stackrel{g}{\stackrel{f}{+}}$ & $\frac{\infty}{\stackrel{0}{0}}$ \\
\hline & $\dot{\Xi}$ & $\underset{r}{\stackrel{P}{r}}$ & $\stackrel{尺}{\approx}$ & ஸै & $\hat{n}$ & $\begin{array}{l}0 \\
\stackrel{2}{0}\end{array}$ & กี & $\begin{array}{l}0 \\
\stackrel{0}{0}\end{array}$ \\
\hline & छ్ & $\begin{array}{l}\hat{\alpha} \\
\text { in }\end{array}$ & $\stackrel{n}{n}$ & $\tilde{\overbrace{}}$ & $\begin{array}{l}\infty \\
n \\
0\end{array}$ & $\stackrel{\forall}{\stackrel{*}{0}}$ & $\vec{i}$ & $\stackrel{\overbrace{}}{\tilde{o}}$ \\
\hline $\begin{array}{l}\vdots \\
\bar{\Xi} \\
\Sigma\end{array}$ & $\begin{array}{l}\dot{x} \\
\text { : }\end{array}$ & $\underset{\dot{m}}{\text { g }}$ & $\stackrel{8}{8}$ & $\sqrt[n]{n}$ & Oे. & $\stackrel{\stackrel{+}{+}}{\circ}$ & $\begin{array}{l}\infty \\
\dot{\infty} \\
\dot{0}\end{array}$ & ஸి \\
\hline & . $\dot{\Xi}$ & $\stackrel{n}{i}$ & $\stackrel{n}{\stackrel{n}{q}}$ & $\vec{\beth}$ & 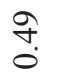 & $\stackrel{\leftrightarrow}{+}$ & $\begin{array}{l}\vec{J} \\
\stackrel{0}{0}\end{array}$ & กี \\
\hline & छ్ & $\underset{\sim}{\Delta}$ & 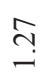 & $\stackrel{\Xi}{\text { S. }}$ & $\tilde{n}$ & กै? & $\stackrel{\leftrightarrow}{+}$ & $\frac{ \pm}{0}$ \\
\hline 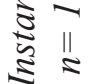 & $\begin{array}{l}\dot{x} \\
\text { Ŭ }\end{array}$ & $\begin{array}{l}\infty \\
\stackrel{0}{0} \\
\dot{\sim}\end{array}$ & $\stackrel{\infty}{n}$ & $\hat{\text { so }}$ & $\begin{array}{l}8 \\
\dot{0}\end{array}$ & $\tilde{n}$ & $\stackrel{\infty}{+}$ & $\frac{1}{0}$ \\
\hline & $\stackrel{\Xi}{\Xi}$ & $\stackrel{\infty}{\stackrel{\infty}{\sim}}$ & $\hat{o}$ & $\stackrel{\circ}{\circ}$ & 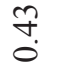 & 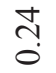 & กै? & $\frac{0}{\frac{1}{0}}$ \\
\hline & $\stackrel{\Xi}{\Xi}$ & $\stackrel{\nexists}{\stackrel{2}{*}}$ & $\begin{array}{l}\infty \\
\infty \\
0 \\
0\end{array}$ & $\stackrel{\imath}{0}$ & $\stackrel{\text { I }}{0}$ & તે & તి & ' \\
\hline $\begin{array}{l}\bar{z} \\
\bar{c} \\
\vdots \\
\vdots\end{array}$ & $\begin{array}{l}\dot{x} \\
\text { ট્g }\end{array}$ & $\stackrel{\infty}{-}$ & $\stackrel{8}{\circ}$ & $\begin{array}{l}+ \\
\infty \\
0\end{array}$ & $\begin{array}{l}n \\
n \\
0\end{array}$ & $\stackrel{\tilde{n}}{\tilde{0}}$ & 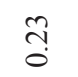 & ' \\
\hline & .̇ & $\stackrel{8}{\stackrel{8}{-}}$ & $\begin{array}{l}\infty \\
\infty \\
0\end{array}$ & $\stackrel{?}{\stackrel{0}{0}}$ & $\stackrel{n}{n}$ & $\frac{n}{0}$ & $\begin{array}{l}0 \\
0 \\
0\end{array}$ & ' \\
\hline & 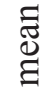 & $\stackrel{0}{=}$ & $\stackrel{0}{0}$ & $\begin{array}{l}n \\
n \\
0\end{array}$ & 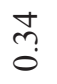 & $\stackrel{2}{\circ}$ & & ' \\
\hline 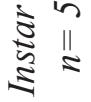 & 离 & $\stackrel{\overbrace{}}{\overbrace{}}$ & $\stackrel{n}{\stackrel{2}{0}}$ & $\begin{array}{l}8 \\
0\end{array}$ & $\stackrel{\infty}{\substack{n \\
0}}$ & $\stackrel{1}{\circ}$ & & 1 \\
\hline & 刍 & $\exists$ & $\begin{array}{l}n \\
0\end{array}$ & $\vec{n}$ & ते & $\stackrel{7}{0}$ & ' & ' \\
\hline & & 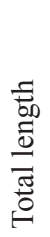 & $\begin{array}{l}\frac{F}{0} \\
\frac{\bar{z}}{3} \\
\dot{x} \\
\dot{\tilde{\sigma}}\end{array}$ & 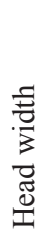 & 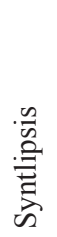 & 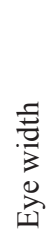 & 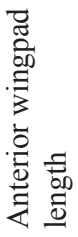 & 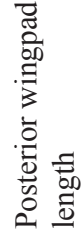 \\
\hline
\end{tabular}

